\title{
Effect of Vermicompost and Moisture Conservation Practices on Yield and Economics of Sesame (Sesamum indicum L.)
}

\author{
Babu Lal $^{1 *}$, L.R. Yadav", Sheeshpal Choudhary ${ }^{1}$, \\ Anju Bijarnia ${ }^{1}$ and Ramesh Choudhary ${ }^{2}$ \\ ${ }^{1}$ Department of Agronomy, Sri Karan Narendra Agricultural University, Jobner, \\ Rajasthan-303 329, India \\ ${ }^{2}$ Department of Agronomy, SKRAU, Bikaner-334006, India \\ *Corresponding author
}

A B S T R A C T

\begin{tabular}{|l|}
\hline Ke y w or d s \\
Sesame, \\
Vermicompost, \\
Mulch, Economics \\
and Yield
\end{tabular}

\section{Introduction}

India is one of the four major players in the global oilseeds/vegetable oils scenario, being one of the important oilseed grower, producer, importer, and exporter (De and Sinha, 2011). Sesame is the key edible oilseed crop in India and cultivated on 15.98 lakh hectares with production of 8.20 lakh tonnes (Anonymous, 2014-15a). This crop is having high quality of oil and meal and also sows wide adaptability for varied agro-climatic conditions. Due to soil and climatic adversities in rainfed ecosystems, the crop suffers from several

\begin{abstract}
A field experiment was conducted at Agronomy farm, S.K.N. College of Agriculture, Jobner (Rajasthan) during kharif, 2016 on loamy sand soil. The experiment comprising of four levels of vermicompost (Control,1.5, 3.0 and 4.5 t/ha) and four moisture conservation practices (control, dust mulch, straw mulch and plastic mulch), thereby making 16 treatment combinations was laid out in randomized block design and replicated thrice. Results indicated that every increase in level of vermicompost from control to @ 3.0 t/ha fetched significantly higher yield viz., seed (834 kg/ha), stalk (2073 kg/ha) and biological yields (2907 kg/ha) over preceding levels, application of @ $4.5 \mathrm{t} / \mathrm{ha}$ provided the gross returns (Rs. 82082/ha) and net returns (Rs. 43964/ha) over @ 3.0 t/ha, @ 1.5 t/ha and control. Application of straw mulch the significantly higher yield $v i z$, seed $(810 \mathrm{~kg} / \mathrm{ha})$, returns (Rs. 45979/ha) over plastic mulch, dust mulch and control.
\end{abstract}


Ahamefule and Peter, 2014). Attributable to the reduction in soil temperature and improved moisture holding capacity of the soil (Lal, 1974). Looking to the above facts, an experiment entitled "Effect of vermicompost and moisture conservation practices on growth parameters, yield attributes and yield of sesame" was under taken.

\section{Materials and Methods}

The experiment was conducted at Agronomy Farm, S.K.N. College of Agriculture, Jobner. Jobner is situated $45 \mathrm{~km}$ west of Jaipur at $26^{\circ} 05^{\prime} \mathrm{N}$ - latitude and $75^{\circ} 28^{\prime} \mathrm{E}$ longitudes and at an altitude of 427 metres above mean sea level in Jaipur district of Rajasthan. The region falls in Agro-climatic zone III-a (Semiarid Eastern Plain). The soil of the experimental field was loamy sand in texture with low in organic carbon $(0.18 \%)$, low in available nitrogen $(132.4 \mathrm{~kg} / \mathrm{ha})$, medium in available phosphorus (18.25 kg/ha) and potassium $(144.26 \mathrm{~kg} / \mathrm{ha}$ ) and slightly alkaline in reaction with $\mathrm{pH} 8.2$.

\section{Results and Discussion}

\section{Effect of vermicompost}

A perusal of data (Table 1 and 2) further indicated that application of vermicompost from control to @ 3.0 t/ha fetched significantly higher yield viz., seed (834 $\mathrm{kg} / \mathrm{ha})$, stalk (2073 $\mathrm{kg} / \mathrm{ha})$ and biological yields $(2907 \mathrm{~kg} / \mathrm{ha})$ over preceding levels, application of @ $4.5 \mathrm{t} / \mathrm{ha}$ provided the gross returns (Rs. 82082/ha) and net returns (Rs. 43964/ha) over@3.0 t/ha, @ 1.5 t/ha and control. The significant increase in seed yield under the influence of vermicompost was largely a function of improved growth and consequently increase in different yield attributes as mentioned above. Further, vermicompost increased the efficiency of added chemical fertilizer in soil and increased rate of humification. Humic acid present in vermicompost enhance the availability of both native and added micronutrients in soil and thus plant growth, yield attributes and ultimately yield increased. These results are in close conformity with those of Raghawendra and Kedar (2008) in chickpea, Sherin and Ahuja (2009) and Ramawtar et al., (2013) in Clusterbean, Meena et al., (2014) in cowpea. The net returns decrease with the each increasing dose of vermicompost, because of the fact the cost involved in each addition of higher dose of vermicompost increase the cost of cultivation whereas the addition in term of returns was low. Similar results were also reported by Kadam et al., (2014) in blackgram.

\section{Effect of moisture conservation practices}

A perusal of data (Table 1 and 2) further indicated that Application of straw mulch the significantly higher yield viz, seed (810 $\mathrm{kg} / \mathrm{ha})$, stalk (2022 $\mathrm{kg} / \mathrm{ha})$ and biological yields (2832 kg/ha), gross returns (Rs. 72900/ha) and net returns (Rs. 45979/ha) over plastic mulch, dust mulch and control. The significant increase in seed yield under the influence of mulching was largely a function of improved growth and consequent increase in different yield attributes as mentioned above. The beneficial effect of organic mulch on seed yield might be due to favourable soil moisture regime and its better utilization in production of large number of seeds possibly by reducing floral abortion, maintenance of a steady flux of assimilates during grain filling, reducing the rate of leaf senescence and maintenance of photosynthetic activity of surviving leaves and enhanced remobilization of pre anthesis assimilates to seed during seed filling. Extended period of moisture availability and lower weed incidence due to organic mulch resulted in a higher dry matter accumulation and thereby, higher stover and biological yield. 
Table.1 Effect of vermicompost and moisture conservation practices on seed, stalk and biological yield and harvest index of sesame

\begin{tabular}{|l|c|c|c|c|}
\hline Treatments & $\begin{array}{c}\text { Seed yield } \\
(\mathbf{k g} / \mathbf{h a})\end{array}$ & $\begin{array}{c}\text { Stalk yield } \\
\mathbf{( k g / h a )}\end{array}$ & $\begin{array}{c}\text { Biological } \\
\text { yield } \\
(\mathbf{k g} / \mathbf{h a})\end{array}$ & $\begin{array}{c}\text { Harvest } \\
\text { Index } \\
(\mathbf{\%})\end{array}$ \\
\hline Vermicompost (t/ha) & & & & \\
\hline Control & 557 & 1514 & 2071 & 26.9 \\
\hline 1.5 & 712 & 1784 & 2496 & 28.5 \\
\hline 3.0 & 834 & 2073 & 2907 & 28.7 \\
\hline 4.5 & 912 & 2264 & 3176 & 28.7 \\
\hline SEm \pm & 28 & 66 & 94 & 0.7 \\
\hline CD $(\mathbf{P}=0.05)$ & 81 & 192 & 271 & NS \\
\hline Moisture conservation practices & & & & \\
\hline Control & 655 & 1697 & 2352 & 27.8 \\
\hline Dust mulch & 760 & 1916 & 2676 & 28.3 \\
\hline Straw mulch & 810 & 2022 & 2832 & 28.5 \\
\hline Plastic mulch & 790 & 2000 & 2790 & 28.2 \\
\hline SEm \pm & 28 & 66 & 94 & 0.7 \\
\hline CD $(\mathbf{P}=0.05)$ & 81 & 192 & 271 & NS \\
\hline CV $(\%)$ & 13 & 12 & 12 & 9.11 \\
\hline
\end{tabular}

Table.2 Effect of vermicompost and moisture conservation practices on gross return and net returns

\begin{tabular}{|l|c|c|}
\hline Treatments & Gross return (Rs./ha) & Net returns (Rs./ha) \\
\hline Vermicompost (t/ha) & & \\
\hline Control & 50130 & 34014 \\
\hline 1.5 & 64080 & 40464 \\
\hline 3.0 & 75060 & 43944 \\
\hline 4.5 & 82080 & 43964 \\
\hline SEm \pm & 1986 & 1161 \\
\hline CD $(\mathrm{P}=0.05)$ & 5736 & 3353 \\
\hline Moisture conservation practices & & \\
\hline Control & 58950 & 33529 \\
\hline Dust mulch & 68400 & 40699 \\
\hline Straw mulch & 72900 & 45979 \\
\hline Plastic mulch & 71100 & 42179 \\
\hline SEm \pm & 1986 & 1161 \\
\hline CD $(P=0.05)$ & 5736 & 3353 \\
\hline CV $(\%)$ & 10 & 10 \\
\hline
\end{tabular}


Similar findings were reported by Verma (2002) in pearlmillet, Sekhon et al., (2005) in soybean and Yadav (2005) in mustard, Chhetri et al., (2015) in blackgram.

\section{References}

Ahamefule, H.E. and Peter, P.C. 2014. Cowpea response to phosphorus fertilizer under two tillage and mulch treatments. Soil Tillage Research 136: 70-75

Anonymous, 2014-15a. Department of Agriculture and Cooperation, Directorate of Statistics and Economics. Ministry of Agriculture, Government of India, New Delhi.

Chhetri, B., Dahal, D., Mahato, S.K., and Khawas, T. 2015 Moisture conservation practices in blackgram (Vigna mungo) based intercropping system under rainfed condition. International Journal of Agriculture Sciences 7 (3): 454-459.

De B, Sinha AC, 2011. Integrated Nutrient Management in Rapeseed: An Integrated Approach for Enhancing the Growth and Yield of Rapeseed (Brassica campestris var yellow sarson). Lambert Academic Publishing, 1-6.

Kadam, Swati R., Kalegore, N. K. and Patil, Snehal R, (2014). Influence of phosphorus, Vermicompost and PSB on yield attributes, seed yield and quality of black gram. Advanced Research Journal of Crop Improvement, 5 (1): 7-10.

Lal, R. 1974. Soil temperature, soil moisture and maize yield from mulched and unmulched tropical soils. Plants and Soil 40 (1): 129-143

Meena, J.S., Verma, H.P. and Pancholi, P. 2014. Effect of fertility levels and biofertilizers on yield, quality and economics of cowpea. Agriculture for Sustainable Development, 2: 162-164.

Raghawendra, S. and Kedar, P., 2008, Effect of vermicompost, rhizobium and DAP on growth, yield and nutrient uptake by chickpea. Journal of Food Legumes, 21 (2): 112- 114.

Ramawtar, Shivran, A.C. and Yadav, B.L. 2013. Effect of fertilizers, vermicompost and sulphur on growth, yield and quality of cluster bean [Cymopsis tetragonoloba (L.)] and their residual effect on yield of succeeding wheat [Triticum aestivum (L.) ]. Legume Research, 36:74-28

Sekhon, N.K., Hira, G.S., Sidhu, A.S. and Thind, S.S. 2005. Response of soybean (Glycine max Mer.) to wheat straw mulching in different cropping seasons. Soil Use and Management, 21 (4): 422426.

Sherin, S. and Ahuja, S. 2009. Effect of organic and inorganic fertilizers on yield and yield attributes of clusterbean [Cymopsis tetragonoloba (L.)]. Field Crop Abstract, 62: 5.

Singh, R.S., Sharma, R.R. and Goyal, R.K. 2007. Interacting effects of planting time and mulching on Chandeler strawberry. Science of Horticulture, 111, 344-351

Verma, O.P. 2002. Effect of nitrogen and mulching on growth and productivity of pearlmillet, Pennisetum glaucum (L.) R.Br. emend stuntz. M.Sc. (Ag.) thesis submitted to Rajasthan Agricultural University, Bikaner (Raj.).

Yadav, R.D. 2005. Effect of mulching and sulphur on mustard [Brassica juncea (L.) Czernj and Cosson] under varying levels of irrigation. Ph.D. (Ag.) thesis submitted to Rajasthan Agricultural University, Bikaner.

\section{How to cite this article:}

Babu Lal, L.R. Yadav, Sheeshpal Choudhary, Anju Bijarnia and Ramesh Choudhary. 2018. Effect of Vermicompost and Moisture Conservation Practices on Yield and Economics of Sesame (Sesamum indicum L.). Int.J.Curr.Microbiol.App.Sci. 7(04): 3454-3457.

doi: https://doi.org/10.20546/ijcmas.2018.704.390 